\title{
Towards a Cultural Sociology of Nations and Nationalism
}

\section{By: Eric Taylor Woods and Mira Debs, 2013}

Published in 2013 in Nations and Nationalism, Vol. 19, Issue 4, pp. 607-614. URL: https://onlinelibrary.wiley.com/doi/abs/10.1111/nana.12036

\section{Introduction}

Scholars in nationalism studies have long been aware of culture's important role in the success of nationalism and the endurance of nations. The 2011 annual conference of the Association for the Study of Ethnicity of Nationalism, which was on the theme of rituals and performances, suggests that culture remains high on the contemporary agenda. Yet, despite this sustained focus on culture, there has been very little engagement with new approaches that have emerged from the rapidly growing fields of cultural studies and cultural sociology. Important scholars associated with those fields are seldom referenced in the pages of this journal.

There is much to be gained from bringing new cultural approaches into closer contact with the study of nations and nationalism. The cultural sociological approach referred to as the 'strong program' is well-suited to such an endeavour. In this introduction, we provide a short overview of the treatment of culture in key texts in nationalism studies and the ways in which we believe the strong program might contribute to its development. Following this, we provide a short outline of each of the articles that comprise this special section.

\section{Nationalism and culture}

It is generally acknowledged that at least some elements of a shared culture among the members of a putative nation are integral to the success and endurance of nations, nationalism and national identity. 
How this shared culture is constructed, maintained and transformed, however, is contested. One important area of contention is the degree to which this can be said to be a top-down process driven by elites.

The dominant view is that the construction of shared culture proceeds nearly wholly from above. Thus, Ernest Gellner (2006 [1983]) points to the role of mass standardised national education systems, while Eugene Weber (1976) implicates the bureaucratic state. Anthony Giddens (1985) similarly focuses on processes associated with a centralising state. Eric Hobsbawm (1990; with Hobsbawm and Ranger 1983) suggests that shared national sentiment is inculcated by way of 'invented traditions' designed by elites. For his part, BenedictmAnderson (1983) puts emphasis on the development of the printing press and subsequent rise of mass media, which draws the reading public into an 'imagined community'.

By contrast, Anthony Smith (e.g. 2009) and other 'ethnosymbolists' (see Grosby and Leoussi 2007; Guibernau and Hutchinson 2004) have sought to correct what they suggest has been an overemphasis on the modern 'inventedness' of nations from above. While they accept that the con- struction of nations is largely a top-down process, Smith (1998: 140-2) nev- ertheless argues that too much focus on the machinations of elites fails to adequately explain why national cultures are often so deeply and widely felt and can persist across generations. Here, the suggestion is that the instantiation of culture is better seen as a process of reinvention, wherein elites draw upon cultural forms that are a priori embedded among the members of a putative nation. For ethnosymbolists, the genealogy of this shared culture, which is manifested in the shared practices, traditions, myths, symbols and memories of 'ethnic cores', can often be traced into the premodern era, notwithstanding the structural changes associated with modernity. Drawing on Durkheim, Smith (2003) has recently suggested that this genealogy also has deep religious roots, thereby implying that nationalism might best be seen as a sacred ideology, which in turn helps to account for its enduring affective power. This latter argument has much in common with the approach of the strong program, which is discussed below.

Building on Smith, John Hutchinson $(1987,2005)$ has produced important work on the cultural processes associated with nations, 
nationalism and national identity. Hutchinson suggests that cultural nationalists (comprising intellectuals, artists, designers, etc.) be seen as 'moral innovators', who seek to culturally regenerate the nation in response to perceived threats. According to Hutchinson (2005: 11553), this effort at regeneration tends to occur through the rediscovery of the ostensibly 'unique' cultural characteristics of the nation, which is often sought in the cultural forms of ordinary citizens. Elites and the masses are thus conceived as being in an interactive, rather than wholly top-down, relationship.

Interestingly, the ethnosymbolist position has been given added empirical strength by the recent turn towards the study of 'everyday nationalism' (e.g. Billig 1995; Brubaker et al. 2006; Edensor 2002; Fox and Miller-Idriss 2008). In this research agenda, scholars are resolutely 'bottom-up' and are concerned with revealing the significance of nationalism and national identity among ordinary people. While demonstrating the myriad of ways in which nationalism is embedded in everyday life, such research has also brought to light how ordinary people often resist, or are indifferent to, the efforts of cultural and political elites to impose or provoke particular nationalisms and national identities, thereby affirming the idea that if such elites are to be successful in their efforts, they must be attuned to ordinary citizens' practices, beliefs and concerns.

If the construction and maintenance of national culture is more of a dialectical process between elites and masses than has been generally understood, how, then, does this occur? Moreover, why do some forms of culture resonate more than others and endure across generations, whereas others are abandoned or transformed? With regard to the latter, although both Smith and Hutchinson have pointed to the role of major events such as war, revolution, immigration and exile as catalysts of transformation, neither they nor their colleagues have fully elucidated the process involved in such a transformation. It is in addressing these kinds of process-oriented questions that the strong program is especially useful.

\section{The strong program in cultural sociology}

Like ethnosymbolism, researchers associated with the strong program in cultural sociology focus on culture as an enduring and relatively independent social force. They are especially interested in how cultural forms (i.e. practices, narratives, myths, symbols and memories) are constructed, maintained and transformed in the 
modern era and how they constrain and enable behaviour. This focus on cultural processes holds potential in moving debates in nationalism studies on the significance of culture forward.

The principal architect of the strong program is Jeffrey Alexander, although important works in its development have also been produced by several of his colleagues and former students (for programmatic statements, see Alexander et al. 2012b; Alexander and Smith 2003). In common with recent developments in ethnosymbolism, Alexander and his colleagues take particular inspiration from Durkheim's (1995 [1912]) Elementary Forms of the Religious Life in order to uncover the significance of culture. The concept of the sacred is important here. For researchers in the strong program, the meanings associated with various forms of culture are the result of their perceived proximity to the sacred. Here, the sacred refers to taken-for-granted norms inherent in the selfunderstanding of society rather than as a synonym for religion or a religious understanding of God (see Lynch 2012). Alexander and his colleagues also make use of concepts such as 'framing', 'coding' and 'weighting' to uncover the processes associated with the construction and maintenance of the meanings of particular cultural forms. Also important is the use of Max Weber's notion of 'carrier groups', which refers to individuals and groups involved in the contestation of such meanings (comprising politicians, artists, intellectuals, journalists, etc). In this view, carrier groups are in many ways analogous to the concept of 'moral innovators' developed by Hutchinson, which was noted above.

The strong program and Alexander's work has attracted much criticism and discussion (Alexander et al. 2009; Beilharz, 2004; Fine 2010; Kivisto 2007; Olick 2010). This has provoked new developments. Responding to the charge that they focus on culture from an overly macroscopic perspective, thereby ignoring the ways in which individuals and groups at the microscopic level are constrained and enabled by culture and may also seek to construct or trans- form it (e.g. Fine 2010), Alexander and his colleagues have integrated insights from performance studies into their approach (see Alexander et al. 2006). In response to the criticism that the strong program downplays too much the role of power in the construction and maintenance of particular cultural forms (e.g. Gartman 2007), Alexander (2011) has begun to specifically discuss the ways in which culture and power interact. Also, to broaden their investigations of 
representations of culture beyond written and oral texts, researchers have begun to turn towards materiality (Alexander et al. 2012a).

Researchers working within the strong program have been particularly engaged in four related but distinct areas of research: the civil sphere, social performance, cultural trauma and iconicity. All four of these areas of research suggest tools for examining cultural processes involved in the construction, maintenance and transformation of nationalisms and national identity.

The 'civil sphere' (Alexander 2006) denotes an imagined space (in a nation, sub-national group, or international group), separate from the economic, political and religious spheres, where struggles over the meaning and bounda- ries of a group occur. Within the civil sphere, social actors seek to identify that which is civil and that which is uncivil, often resulting in the exclusion of certain kinds of actors and groups. The process of reintegrating excluded groups, termed civil repair, is driven by carrier groups, which draw on shared cultural forms to emotively and psychologically engage the conscience of the group. The American civil rights movement (Alexander 2006), the African National Congress' appeal to an international audience in its struggle against apartheid (Thörn 2006), Obama's election (Alexander 2010) and the recent Egyptian 'Revolution' (Alexander 2011) are examples of the power of narratives of civil repair to cause political change and, in the process, redefine a group.

If the theory of the civil sphere provides a framework for analysing how competing actors in society engage with culture in order to effect social and political change, the theory of social performance helps delineate why one group is successful in conveying their intended message while another is not. In order to foreground the role of agency while still keeping an eye on the ways in which agents are embedded in wider cultural forms, the theory of social performance combines key works in performance studies, including Victor Turner (1974) and Richard Schechner (1988), with important studies associated with symbolic interactionism, particularly John Austin (1962) and Erving Goffman (1959). The theory of social performance analogises symbolic action as a theatrical performance, whose aim is to connect psychologically and emotionally with the wider group (Alexander et al. 2006). To do so, social performers draw on elements of a group's shared culture and make use of their access to social power and available communication technologies. If 
successful, social performers are seen to have 'fused' with their audience and their performance is judged to have been 'authentic'. Jonathan Wyrtzen's article in this volume draws on the theory of social performance to analyse anti-colonial nationalist protests in 1930s Morocco.

The theory of cultural trauma (Alexander et al. 2004; Eyerman et al. 2011) provides a model for examining how narratives about collective suffering, such as war, genocide or displacement, are constructed and, in some cases, trans- form a group's identity. Cultural traumas are argued to be constructed and contested by carrier groups, which performatively seek to have a particular event acknowledged (or not) by the wider group as traumatic. If the trauma narrative resonates with the wider group, it can be integrated into its collective identity. Two papers in this themed section engage with the theory of cultural trauma. Mira Debs' analysis of post-independence India demonstrates how trauma narratives can be used to convey a range of meanings about the nation, and how they are transformed over time in response to historical circum- stances. Gulay Turkmen uses the theory of cultural trauma to examine the link between a largely unacknowledged cultural trauma, the massacre of Armenians by the Turkish state, and its re-emergence after the 2007 assassination of Armenian journalist Hrant Dink.

Lastly, the strong program's theory of iconicity pays attention to ways in which cultural forms become instantiated in material objects (Alexander 2008; Alexander et al. 2012a). This is an avenue of study familiar to many nation- alism scholars (e.g. Boswell and Evans 1999; Davis 1996; Kohl and Fawcett 1995; Kohl et al. 2007; Zerubavel 1996). Integrating Durkheim's (1995 [1912]) emphasis on collective totems with a cultural approach to material culture that emphasizes the fluidity of an object's meaning (Appadurai 1986; Douglas and Isherwood 1979; Kopytoff 1986; Woodward 2007), the study of iconicity provides a framework for bringing to light how and why certain objects are transformed into icons for the members of a group. Fiona Rose Greenland's article in this volume explores the theory of iconicity in relation to the significance of the Parthenon Marbles for narratives of British national identity.

The four areas of research described here provide tools that are relevant to nationalism studies. We will leave it to the contributors to this special section to demonstrate this in greater depth. Before proceeding, however, we would like to stress that it is our hope that 6 
the application of insights from the strong program will not only be of use to the scholarship on nationalism, but that the strong program will also be enhanced through further engagement with nationalism. In the modern era, one of the clearest expressions of the Durkheimian desire for social solidarity is nationalism.

\section{Outline}

The contributions in this special section draw on insights from the strong program in order to throw new light on questions integral to the study of nations and nationalism. In order to provide a broadly comparative window into the possibilities offered by this endeavour, the contributions focus on a wide variety of regions and time periods.

In the first article, Jonathan Wyrtzen engages with the theory of social performance to explain why certain national narratives resonated more than others via a case study of postcolonial Morocco. In particular, Wyrtzen seeks to resolve how a Muslim prayer ritual was successfully re-purposed by Moroccan nationalists to galvanise a mass movement against French rule.

In the second article, Mira Debs focuses our attention on when and why particular events become national cultural traumas through a comparative analysis of the impact of the assassination of Mahatma Ghandi and the partition of Indian and Pakistan on Indian national identity.

In the third article, Fiona Rose-Greenland addresses how and why certain objects become national icons through an analysis of the process by which the Parthenon Marbles were transformed into symbols of British National identity.

In the last case study, Gulay Turkmen employs cultural trauma theory to examine the impact of Hrant Dink's assassination on the Turkish nation. Turkmen demonstrates that although the assassination initially seems to have had the potential to become a divisive cultural trauma, the performance of solidarity between Turks and Armenians at Dink's funeral created a feeling of temporary civil repair, even though the status of Armenians in Turkey remained unchanged. 
To conclude, Jeffrey Alexander offers some theoretical reflections on the implications of this project and discusses potential future research.

\section{Note}

1 For an excellent discussion of the relationship between nations and their ethnic cores in the work of Anthony Smith, see Kaufmann and Zimmer 2004.

\section{References}

Alexander, J. C. 2006. The Civil Sphere. Oxford: Oxford University Press.

Alexander, J. C. 2008. 'Iconic experience in art and life: beginning with Giacometti's "standing woman" ', Theory, Culture and Society 25, 5: 1-19.

Alexander, J. C. 2010. The Performance of Politics: Obama's Victory and the Democratic Struggle for Power. Oxford: Oxford University Press.

Alexander, J. C. 2011. Performance and Power. New York: Polity Press.

Alexander, J. C. et al. 2004. Cultural Trauma and Collective Identity. Berkeley: University of California Press.

Alexander, J. C. et al. (ed.) 2006. Social Performance: Symbolic Action, Cultural Pragmatics and Ritual. Cambridge: Cambridge University Press.

Alexander, J. C. et al. 2009. Remembering the Holocaust: A Debate. Oxford: Oxford University Press.

Alexander, J. C. et al. (ed.) 2012a. Iconic Power: Materiality and Meaning in Social Life. London: Palgrave MacMillan.

Alexander, J. et al. (ed.) 2012b. Oxford Handbook of Cultural Sociology. Oxford: Oxford University Press.

Alexander, J. C. and Smith, P. 2003. 'The strong program in cultural sociology: elements of a structural hermeneutics' in J. C. Alexander (ed.), The Meanings of Social Life: A Cultural Sociology. Oxford: Oxford University Press.

Anderson, B. 1983. Imagined Communities: Reflections on the Origin and Spread of Nationalism. London: Verso.

Appadurai, A. (ed.) 1986. The Social Life of Things. Cambridge: Cambridge University Press.

Austin, J. L. 1962. How to Do Things with Words. Oxford: Clarendon Press.

Beilharz, P. (ed.) 2004. 'The Alexander Effect', Special Issue of Thesis eleven: critical theory and historical sociology 79,3 .

Billig, M. 1995. Banal Nationalism. London: Sage.

Boswell, D. and Evans, J. (eds.) 1999. Representing the Nation, A Reader: Histories, Heritage and Museums. New York: Routledge.

Brubaker, R. et al. 2006. Nationalist Politics and Everyday Ethnicity in a Transylvanian Town. 
Princeton: Princeton University Press.

Davis, R. 1996. 'Iconography of Ram's Chariot' in D. Ludden (ed.), Contesting the Nation: Religion, Community, and the Politics of Democracy in India. Philadelphia: University of Pennsylvania Press.

Douglas, M. and Isherwood, B. 1979. The World of Goods. New York: Basic Books. Durkheim, E. 1995. [1912]. The Elementary Forms of Religious Life. Trans. K. Fields. New York: Free Press.

Edensor, T. 2002. National Identity, Popular Culture and Everyday Life. Oxford: Berg.

Eyerman, R. et al. (ed.) 2011. Narrating Trauma: On the Impact of Collective Suffering. Boulder: Paradigm.

Fine, G. A. 2010. 'The sociology of the local: action and its publics', Sociological Theory 28: 355-76.

Fox, J. E. and Miller-Idriss, C. 2008. 'Everyday nationhood', Ethnicities 8, 4: 536-62.

Gartman, D. 2007. 'The strength of weak programs in cultural sociology: a critique of Alexander's critique of Bourdieu', Theory and Society 36: 381-413.

Gellner, E. 2006. [1983]. Nations and Nationalism. Hoboken: Wiley-Blackwell. Giddens, A. 1985. The Nation-State and Violence. Cambridge: Polity Press.

Goffman, E. 1959. The Presentation of Self in Everyday Life. New York: Random House.

Grosby, S. E. and Leoussi, A. S. (eds.) 2007. Nationalism and Ethnosymbolism: History, Culture and Ethnicity in the Formation of Nations. Edinburgh: Edinburgh University Press.

Guibernau, M. and Hutchinson, J. (eds.) 2004. History and National Destiny: Ethnosymbolism and its Critics. London: Wiley-Blackwell.

Hobsbawm, E. 1990. Nations and Nationalism since 1780: Programme, Myth and Reality. Cambridge: Cambridge University Press.

Hobsbawm, E. and Ranger, T. (eds.) 1983. The Invention of Tradition. Cambridge: Cambridge University Press.

Hutchinson, J. 1987. The Dynamics of Cultural Nationalism: The Gaelic Revival and the Creation of the Irish Nation State. London: Allen \& Unwin.

Hutchinson, J. 2005. Nations and Zones of Conflict. London: Sage.

Kaufmann, E. and Zimmer, O. 2004. " "Dominant ethnicity" and the "ethnic-civic" dichotomy in the work of A. D. Smith', Nations and Nationalism 10, 1: 63-78.

Kivisto, P. (ed.) 2007. 'Review symposium on the civil sphere', Sociological Quarterly 48, 4: 587659.

Kohl, P. and Fawcett, C. 1995. Nationalism, Politics and the Practice of Archaeology. Cambridge: Cambridge University Press.

Kohl, P. et al. (ed.) 2007. Selective Remembrances: Archaeology in the Construction, Commemoration and Consecration of National Pasts. Chicago: University of Chicago Press.

Kopytoff, I. 1986. 'The cultural biography of things: commodization as process' in A. Appadurai 
(ed.), The Social Life of Things. Cambridge: Cambridge University Press.

Lynch, G. 2012. The Sacred in the Modern World. Oxford: Oxford University Press.

Olick, J. K. 2010. 'What is "the Relative Autonomy of Culture?" ' in J. R. Hall et al. (ed.), Sociology of Culture: A Handbook. London: Routledge. Schechner, R. 1988. Performance Theory. London: Routledge.

Smith, A. D. 1998. Nationalism and Modernism: A Critical Survey of Recent Theories of Nations and Nationalism. London: Routledge.

Smith, A. D. 2003. Chosen Peoples: Sacred Sources of National Identity. Oxford: Oxford University Press.

Smith, A. D. 2009. Ethno-Symbolism and Nationalism: A Cultural Approach. London: Taylor and Francis.

Thörn, H. 2006. Anti-Apartheid and the Emergence of a Global Civil Society. London: Palgrave MacMillan.

Turner, V. 1974. Dramas, Fields and Metaphors: Symbolic Action in Human Society. Ithaca: Cornell University Press.

Weber, E. 1976. Peasants into Frenchmen. Palo Alto: Stanford University Press. Woodward, I. 2007. Understanding Material Culture. London: Sage.

Zerubavel, Y. 1996. 'The forest as a national icon: literature, politics, and the archaeology of memory', Israel Studies 1, 1: 60-99. 